\title{
Tubercle disease of sugar beet roots (Beta vulgaris) found in Poland is neither caused by Xanthomonas beticola nor by tumorigenic Agrobacterium/Rhizobium
}

\author{
E. Moliszewska ${ }^{1}$ (D) M. Nabrdalik ${ }^{1} \cdot$ J. Puławska ${ }^{2} \cdot$ J. Piszczek $^{3}$
}

Received: 11 February 2018/Accepted: 31 July 2018/Published online: 2 August 2018

(c) The Author(s) 2018

\begin{abstract}
Symptoms of tubercle disease known also as Xanthomonas gall were noticed in Poland in 2014-2017. Roots with disease symptoms showed the reduction of sucrose content compared to the healthy ones. In the literature, there are two gall diseases described: tubercle disease (also known as Xanthomonas gall) and crown gall, which is caused by Rhizobium radiobacter (syn. Agrobacterium tumefaciens). None of the bacterial strains isolated from the malformed tissues were identified as the bacterial pathogen responsible for causing Xanthomonas gall or crown gall. The result was confirmed by searching for the presence of T-DNA, which was not found. Our conclusion is that the tubercle disease observed in Poland is not caused by $R$. radiobacter.
\end{abstract}

Keywords Xanthomonas gall $\cdot$ Rhizobium radiobacter $\cdot$ Agrobacterium tumefaciens $\cdot$ Tubercle disease $\cdot$ Sugar beet

Symptoms of $X$. beticola disease were first documented on sugar beet roots about one hundred years ago in the United States and have been observed only occasionally since then. Despite this, the disease is frequently described, especially in European literature (Benada et al. 1984; Kozyrovskaya et al. 1984; Nyvall 1989; Drycott 2006; Lazarev 2009; Harveson et al. 2009). However, in recent times, symptoms of the disease called "tuberculosis" were observed on sugar beet roots in 2014 in the central part of Poland (supplementary materials, photos $1-5$ ). The symptoms included unusual tumor-like deformations located on the roots' head. Some roots had galls that covered the

Electronic supplementary material The online version of this article (https://doi.org/10.1007/s41348-018-0183-3) contains supplementary material, which is available to authorized users.

E. Moliszewska

ewamoli@uni.opole.pl

1 Department of Technical and Environmental Sciences, University of Opole, Kominka 6A, 45-032 Opole, Poland

2 Research Institute of Horticulture, ul. Konstytucji 3 Maja 1/3, 96-100 Skierniewice, Poland

3 Institute of Plant Protection - National Research Institute, Regional Experimental Station, Pigwowa 16, 87-100 Torun, Poland entire surface and were larger and more irregular than previously described galls (supplementary materials, photos 1-5). These symptoms were observed again in Poland from 2015 to 2017. Each year diseased roots were collected for chemical analysis which was done in the laboratory of Kutnowska Hodowla Buraka Cukrowego (KHBC, Kutnowska Sugar Beet Breeding) by VENEMA automatic system. The analysis of the roots' quality showed that the reduction of sucrose content was $1.0-1.5 \%$ (in 2015) and $3.8-6.2 \%$ (in 2016) when compared to healthy roots. In 2017 , sucrose content in malformed roots was about $15 \%$. We did not find the causal agent responsible for the disease, and we suggest that the currently known pathogen of the tuberculosis called also "Xanthomonas gall" $-X$. beticola, does not exist (Moliszewska et al. 2016). Therefore, our search was targeted to discover other potential bacterial pathogens which could be responsible for the disease symptoms observed.

\section{Laboratory investigations for pathogens}

We have isolated bacteria present in the deformed root tissues. Tissues were macerated in phosphate-buffered saline (PBS), and the homogenate was applied onto nutrient agar (NA, BioMaxima), nutrient agar with an addition 
of $1 \%$ saccharose (NAS, BioMaxima), nutrient agar with an addition of $0.5 \%$ yeast extract (YNA, BioMaxima), Pseudomonas agar (PsA, Biocorp), malt extract agar (MEA, Biocorp), agar with yeast extract, dextrose and calcium carbonate (YDC, BioMaxima) and agar with $2 \%$ sucrose and peptone (SPA, BioMaxima). The incubation was conducted in $25 \pm 2{ }^{\circ} \mathrm{C}$ for $48 \mathrm{~h}$. The preliminary identification of isolated mono-bacterial cultures, with characteristic yellow colonies, was carried out on the basis of macroscopic and microscopic description and by API tests (ID32 GN and Api 20E) according to the producer recommendations (BioMerieux). For bacteria identification, we used also partial sequencing of the $16 \mathrm{~S}$ rDNA obtained by PCR method with primers: forward-20F (5'AAGTGAAGAGTTTGATCCCTG-3') and reverse-17R $\left(5^{\prime}-\mathrm{GACTTCACCCCAGTCAT-3^{ \prime }}\right)$ and with the use of Direct PCR Kits-Terra PCR Direct Polymerase Mix (Clontech, Mountain View, CA, USA = Takara Bio USA). The primers $20 \mathrm{~F}$ and $17 \mathrm{R}$ for PCR assay were designed by BLAST tool (NCBI) to obtain their partial 16S rRNA gene fragments of different Xanthomonas genus strains with a predicted PCR product length of $1500 \mathrm{bp}$. According to the results, we have identified Pantoea agglomerans and Pseudomonas plecoglossicida/P. putida. The other isolated endophytic bacteria were identified with the following primers: 27F (5'-AGAGTTTGATCTTGGCTCAG-3') and 1492R (5'-ACGGTTACCTTGTTACGACTT-3') (Kim et al. 2012). Isolated bacteria were identified to genera and species like: Pseudomonas putida, P. moraviensis P. fulva, $P$. plecoglossicida, Microbacterium phyllosphaerae, $M$. foliorum, Bacillus subtilis B. megaterium, B. amyloliquefaciens, Brevundimonas vesicularis Brevibacterium casei, Arthrobacter sp., A. phenanthrenivorans, Phyllobacterium myrsinacearum Rhodococcus globerulus, Rhodococcus erythropolis, Stenotrophomonas chelatiphaga, S. rizophila, Peanarthrobacter aurescens, Acinetobacter johnsonii, Mesorhizobium sp., Mycobacterium sp., Bosea sp., Kocuria sp., Pseudoclavibacter sp. None of the isolated bacteria were identified as Xanthomonas sp, and Agrobacterium/ Rhizobium radiobacter was also not detected.

\section{Pathogenicity experiments}

To check, if bacteria isolated from malformed roots have pathogenic properties, we have prepared the inoculation experiments.

\section{Experiment 1}

For this purpose, 1-month-old roots of sugar beets, grown in phytotron in pots filled with sterile bentonite $(\mathrm{pH} \approx 7)$, were inoculated by injuring with pure bacteria cultures of representative strains (Pseudomonas $\mathrm{sp}$. and $P$. agglomerans). No disease symptoms were observed after 2 months of culturing.

\section{Experiment 2}

Additionally, we cultured sugar beets in pots where dried galls from diseased sugar beet roots, collected in July 2016, were crushed and used for inoculation. Sugar beet roots were injured in the part above the soil surface using scalpel to simplify infection. The experiment lasted 6 months. No disease symptoms were observed in this experiment.

\section{Experiment 3}

The experiment was conducted on the experimental field (on the KHBC area) on which "tuberculose" symptoms were observed in previous years and were also observed in the current year. In the field experiment, 10-week-old plants were treated by pure cultures of $P$. agglomerans obtained in 2015 from diseased roots. We used $5 \mathrm{ml}$ of the culture $\left(\mathrm{cfu}=1 \times 10^{6} / \mathrm{ml}\right)$ for each plant in the row consisting of 30 plants. The experiment was consisted of five replicates, with no treated control. To avoid a false result, we counted all plants present with visible symptoms of the roots' malformations. During harvest, plants with those symptoms were counted once more and the number of diseased plants was compared. We observed no significant differences in the number of diseased plants and disease occurrence between infected and uninfected plants in this experiment.

\section{Additional laboratory investigations for pathogens}

Additionally, in 2015 sugar beets from two locations and in 2016-from three locations, in which the disease was observed in both years, were tested for crown gall causal agents. To check if the deformations were caused by tumorigenic bacteria belonging to Agrobacterium/Rhizobium genus, isolation of bacteria was carried out on selective media $\mathrm{Mg}+\mathrm{TE}$ and $1 \mathrm{~A}+2 \mathrm{E}$ (Puławska et al. 2016). Obtained bacterial colonies were pre-identified as Agrobacterium/Rhizobium by $23 \mathrm{~S}$ rDNA-based multiplex PCR (Puławska et al. 2006) and identified as possessing Ti plasmid (necessary for tumor formation on plants) by tms 2 gene-based PCR (Puławska and Sobiczewski 2005). Additionally, selected isolates were identified by sequence analysis of $16 \mathrm{~S}$ rDNA. Isolated bacteria were identified to genera and species like: Pseudomonas lurida, Phyllobacterium ifriqiyense and different species of Rhizobium characteristic for soil environment. We also isolated 
bacteria belonging to Agrobacterium skierniewicense (Puławska et al. 2012a) and A. nepotum (Puławska et al. $2012 \mathrm{~b}$ ), but none of the isolates was tumor-inducing.

\section{Conclusion}

Our conclusion is that the tubercle disease (syn. Xanthomonas gall) is not caused by bacterial pathogens described in the literature, especially not by Rhizobium radiobacter (syn. Agrobacterium tumefaciens). Additional investigations for the causal agent of the disease are requested. Simultaneously, we found that investigations for endophytic bacteria and their role in sugar beets are interesting and hopeful for future research.

\section{Compliance with ethical standards}

Conflict of interest All authors declare that they have no conflict of interest.

Open Access This article is distributed under the terms of the Creative Commons Attribution 4.0 International License (http://creative commons.org/licenses/by/4.0/), which permits unrestricted use, distribution, and reproduction in any medium, provided you give appropriate credit to the original author(s) and the source, provide a link to the Creative Commons license, and indicate if changes were made.

\section{References}

Benada J, Špaček J, Šedivy J (1984) Atlas chorób i szkodników buraka. PWRiL, Warszawa
Drycott AP (2006) Sugar beet. Blackwell, Oxford

Harveson RM, Hanson LE, Hein GL (eds) (2009) Compendium of beet diseases and pests, 2nd edn. APS Press, St. Paul

Kim SH, Jeong HS, Kim YH, Song SA, Lee JY, Oh SH, Kim HR, Lee JN, Kho W-G, Shin JH (2012) Evaluation of DNA extraction methods and their clinical application for direct detection of causative bacteria in continuous ambulatory peritoneal dialysis culture fluids from patients with peritonitis by using broad-range PCR. Ann Lab Med 32:119-125. https://doi.org/10.3343/alm. 2012.32.2.119

Kozyrovskaya NA, Gvozdyak RI, Muras VA, Kordyum VA (1984) Changes in properties of phytopathogenic bacteria effected by plasmid pRD1. Arch Microbiol 137(4):338-343

Lazarev AM (2009) Xanthomonas beticola. Interactive agricultural ecological atlas of Russia and neighboring countries. Economic Plants and their diseases, pests and weeds (Online). http://www. agroatlas.ru/en/content/diseases/Beta_alba/Beta_alba_Xanthomo nas_beticola. Accessed 20 May 2018

Moliszewska E, Nabrdalik M, Piszczek J (2016) Tubercle disease (Xanthomonas beticola) and other gall-malformed diseases of sugar beet roots: a review. J Plant Dis Prot 123(5):197-203. https://doi.org/10.1007/s41348-016-0032-1

Nyvall RF (1989) Field crop diseases handbook. Van Nostrand Reinhold, Springer, New York

Puławska J, Sobiczewski P (2005) Development of a semi-nested PCR based method for sensitive detection of tumorigenic Agrobacterium in soil. J Appl Microbiol 98:710-721. https://doi.org/10.1111/j.1365-2672.2004.02503.x

Puławska J, Willems A, Sobiczewski P (2006) Rapid and specific identification of four Agrobacterium species and biovars using multiplex PCR. Syst Appl Microbiol 29:470-479

Puławska J, Willems A, Sobiczewski P (2012a) Rhizobium skierniewicense sp. nov. isolated from tumors on chrysanthemum and cherry plum. Int J Syst Evol Microbiol 62(Pt 4):895-899

Puławska J, Willems A, De Meyer SE, Sule S (2012b) Rhizobium nepotum sp. nov. isolated from tumors on different plant species. Syst Appl Microbiol 35:215-220

Puławska J, Warabieda W, Ismail E (2016) Identification and characterization of bacteria isolated from crown galls on stone fruits in Poland. Plant Pathol 65:1034-1043 